\title{
Szenzorral támogatott inzulinpumpa használata extrém fizikai terhelés során 1-es típusú diabetes mellitusban
}

\author{
Török András dr., ${ }^{(1,2)}$ Brasnyó Pál dr. ${ }^{(3)}$
}

\begin{abstract}
Öszefoglalás
A testmozgás jótékony hatása a cukorbetegségben evidencia, az anyagcserére gyakorolt pozitiv hatása egyértelmü, ahogy a diabetes kialakulásának megelözésében játszott szerepe is. Ennek ellenére számos 1-es típusú diabetesszel élö egyén tart a rendszeres testmozgástól a hypoglykaemia veszélye miatt. A hagyományos inzulinkezeléshez és a szenzor nélküli inzulinpumpa használatához képest a szenzoros inzulinpumpával a nem kivánt vércukoresések veszélye jelentösen csökkenthetö. A szerzök 15, szenzoros inzulinpumpát használó 1-es típusú fiatal felnött cukorbeteg fokozott fizikai terhelés mellett rögzitett szöveti cukorszintadatait dolgozták fel. Az irodalmi adatokkal egyezöen azt találták, hogy a szenzoros inzulinpumpa használatával a súlyos (külsö segitséget igénylö) és közepesen súlyos (kifejezett klinikai tünetekkel és panaszokkal kisért) hypoglykaemiák is kivédhetök, még ilyen extrém körülmények között is.

Kulcsszavak: szenzorral vezényelt inzulinpumpa, extrém fizikai terhelés, szöveti cukorszint monitorozás

\section{Effect of threshold suspend insulin pump therapy during extreme physical activity among type 1 diabetic patients}

Summary: Regular physical activity is an integral part of diabetes management and also plays an important role in diabetes prevention. Fear of hypoglycemia is the strongest barrier to regular physical activity in patients with type 1 diabetes. Sensor augmented insulin pump therapy can reduce the rate of severe and moderate hypoglycemia episodes compared with standard insulin and insulin pump (without sensor) therapy. Glycemic status of 15 young adults with type 1 diabetes during extreme physical activity was analysed in this study. Our results showed that sensor-augmented pump therapy reduced the combined rate of severe (requiring help) and moderate hypoglycemia (accompanied with typical clinical signs) in patients with type 1 diabetes during extreme physical activity.

Key words: sensor-augmented insulin pump, severe physical exercise, continuous tissue glucose monitoring
\end{abstract}

\section{Rövidítések}

LGS: inzulin felfüggesztése alacsony cukorértéknél (low glucose suspend); PLGM: inzulinfelfüggesztés az alacsony értékhez közelítve (predictive low glucose management)

K evés olyan kérdés van a diabetológiában - tágabb értelemben a medicinában általában -, amelyben annyira egységes az álláspont, mint a testmozgás jótékony hatása. Evidenciaként szerepel a Magyar Diabetes Társaság szakmai irányelvében, kiemelve a vércukorszintre gyakorolt jótékony hatását, valamint a kardiovaszkuláris kockázat csökkentésében játszott szerepét. ${ }^{1}$

A téma jelentőségét jelzi, hogy cikkek tucatjai taglalják a kérdést, jó részükben igen komoly esetszámot felvonultatva. 
Nehéz lenne ezek közül egyet kiemelni, talán az egyik legimpozánsabb munka német szerzők tollából született. A több mint 18000 fő adatait feldolgozó vizsgálatukban a rendszeres fizikai aktivitást összefüggésbe hozzák a jobb anyagcserével (kisebb $\mathrm{HbA}_{1 \mathrm{c}}$, ritkábban kialakuló diabeteses ketoacidózis), valamint a kardiovaszkuláris rizikófaktorok tekintetében (alacsonyabb diastolés vérnyomás, alacsonyabb BMI, összességében jobb lipidprofil) is jótékony hatásúnak találták, ráadásul a retinopathia és a kóros albuminuria is gyakrabban fordult elő az inaktív 1-es típusú diabetesesek körében. ${ }^{2}$ Leszögezhetjük tehát, hogy a rendszeres aktív testmozgás jótékony hatása evidens „orvosi” értelemben, a laboratóriumi módszerekkel precízen mérhető változók tekintetében.

Fontos emellett az is, hogy gondozottjaink hogyan érzik magukat a mindennapokban, az orvosi rendelőn kívül. A testi fittség hozzájárul az életminőség javulásához is. ${ }^{3}$ Ráadásul a megfelelő fizikai állapot nemcsak a már ismert és kezelt cukorbetegek számára hasznos, hanem a diabetes kialakulásának lehetőségét is csökkentheti. ${ }^{4,5,6}$

Az 1-es típusú diabetesesekre fókuszálva azt látjuk, hogy gondozottjaink egy része tisztában van ugyan a testmozgás jótékony szerepével, de - a betegek nagyobb részére jellemzően - a hypoglykaemiától való félelem óvatosabbá teszi őket, ahogy arról többek között egy kanadai munkacsoport is beszámolt. ${ }^{7}$ A dilemma feloldásában - a megfelelően beállított kezelés és a jó betegedukáció mellett - nagy segítséget nyújthat a folyamatos szöveti glukózmonitor (CGM) alkalmazása. ${ }^{8}$

A CGM elősegíti a $\mathrm{HbA}_{1 \mathrm{c}}$ csökkenését, valamint szerepet játszik a napszakos vércukor-ingadozás mérséklésében is, ${ }^{9}$ legyen szó akár naponta több alkalommal pennel adagolt inzulinról, akár inzulinpumpa-kezelésről. Nagy esetszámot felvonultató vizsgálatok bizonyítják a pumpakezelés előnyét hypoglykaemiák tekintetében a pennel történő kezeléssel szemben. Egy német munkacsoport több mint 30000 gyermek, serdülő és fiatal felnőtt 1-es típusú diabeteses adatait elemezve azt találta, hogy a pumpahasználók körében szignifikánsan ritkábban fordult elő súlyos vércukoresés a pent használókkal összevetve (9,55 vs. 13,97 alkalom/100 betegév). ${ }^{10}$

Az inzulinpumpa és az azzal kommunikálni képes szenzor esetében még nagyobb biztonságban lehetnek a felhasználók. ${ }^{11} \mathrm{~A}$ technológia fejlődésével és egyre megbízhatóbbá válásával a vonatkozó szakirodalom is egyre bővült, mostanra mértékadó metaanalízisek is rendelkezésre állnak. ${ }^{12,13}$

A szenzorok nem közvetlenül a vér cukortartalmát, hanem a szöveti glukózszintet mérik. Ez a két érték nem pontosan ugyanaz minden pillanatban, de igen jó korrelációt mutatnak, így a szenzorok által mért cukrokértéket - ritka kivételektől eltekintve - a mindennapokban értékelhetjük valódi szérumglukózértékként. A korábbi modellek (pl. MiniMed Paradigm Veo) szenzor segítségével alacsony szöveti cukorszintet észlelve felfüggesztették a bázisként szolgáló inzulin adagolását (Low Glucose Suspend - LGS). A Magyarországon jelenleg elérhető legújabb modell (Medtronic Minimed 640G) azonban már akkor leállítja a bázisinzulin adagolását, ha a szöveti cukorszint a hypoglykaemia közelében van és a cukorcsökkenés üteme alapján rövid időn (30 percen) belül várhatóan még inkább megközelíti azt (csak 1,1 mmol/l-es értékkel haladja meg a beállított hypoglykaemiahatárt). Ezzel mintegy „előre jelzi” a vércukoresés bekövetkeztét (Predictive Low Glucose Management - PLGM).

\section{Betegek, módszerek}

2016 szeptemberében és 2017 augusztusában a Medtronic Hungária Kft. jóvoltából részt vehettünk egy-egy háromnapos túrán a szlovákiai Csorba-tónál: a jelen munkánkban az ott tapasztaltakról számolunk be. Mindkét alkalommal nemzetközi csapat gyült össze. A túrán 9, illetve 6 fő 1 -es típusú diabetes miatt Medtronic inzulinpumpát (Minimed Paradigm Veo és Minimed 640G) használó fiatal magyar felnőtt mellett szlovák, cseh, szlovén és román nemzetiségű cukorbetegek vettek részt a kísérő egészségügyi csapat mellett. A gyülekező az első napon folyamatos volt, ekkor a pihenés, rákészülés volt a program. Maga a túra a második napon kora hajnalban indult, a cél a lengyel-szlovák határon található, 2503 méter tengerszint feletti magasságban elhelyezkedő Tengerszem-csúcs (Rysy) megmászása volt. Az út során 1144 méter szintkülönbséget küzdöttünk le több pihenő közbeiktatásával, majd a csúcsot elérve ugyanazon az úton tértünk vissza a szálláshelyre. Az átlagosan 10-11 óra alatt nehéz hegyi terepen megtett út teljes hossza $27,86 \mathrm{~km}$ volt. A harmadik nap az aktív 
pihenésé volt, a vállalkozók ekkor falmászást és raftingolást próbálhattak ki.

Munkánk a 15 magyar résztvevő (3 nő és 12 férfi, BMI: 23,51 $\pm 3,43 \mathrm{~kg} / \mathrm{m}^{2}$, átlagos életkor: $27,48 \pm 5,23$ év volt, diabetesük a túra idején $13,38 \pm 7,16$ éve volt ismert; adatok átlag \pm SD-ben megadva) megfigyelésének eredményeit mutatja be. Edzettségi szintjük változó volt. Közülük 2 fő rendszeresen, hetente több alkalommal sportolt, a többiek átlagosan heti egy alkalommal vagy ritkábban. Anyagcseréjük alapvetően rendezett volt $\left(\mathrm{HbA}_{1 \mathrm{c}}: 7,00 \pm 0,54 \%\right)$, érdemi diabeteses szövődményről nem tudtak. Inzulinigényük a három nap során átlagosan 41,67士10,98 E volt. Ez megfelelt 0,57 $\pm 0,12$ E/testtömeg-kilogrammnak. Megérkezéskor mindenkire szenzort helyeztünk fel, majd a túra harmadik napján azt levéve, közösen elemeztük az adatokat. A résztvevők közül öt fő jegyezte rendszeresen a bevitt szénhidrát menynyiségét. A többieknél előfordult, hogy néhány kisebb étkezést nem regisztráltak, így az ő adataikat e tekintetben nem elemeztük. A kiértékelés során párosított t-próbával hasonlítottuk össze a túra első és második, illetve a második és harmadik napján rögzített változókat.

\section{Eredmények}

Nem meglepő módon a túra napján mindenkinek jelentősen kisebb volt az inzulinigénye az előző naphoz képest $(45,34 \pm 12,81 \mathrm{E}$ vs. 36,26 $\pm 12,41 \mathrm{E}$, $\mathrm{p}=0,001)$, a harmadik napon azonban a hosszan tartó intenzív mozgás befejezését követően ismét visszaemelkedett $(36,26 \pm 12,41$ vs. 42,44 $\pm 10,26 \mathrm{E}$, $\mathrm{p}=0,012)$. A túra során a bázisütemet mindenki csökkentette kisebb-nagyobb mértékben, ennek megfelelően az összességében is kisebb mértékű össz-inzulinigény drasztikusan a bólus irányába tolódott el (bázis/bólus arány: 1,31 0,77 vs. $0,95 \pm 0,55, \mathrm{p}<0,0001)$. Érdekes módon a harmadik napra ez emelkedett ugyan, de csak kismértékben $(0,95 \pm 0,55$ vs. $0,97 \pm 0,47, p=0,804)$.

Hiába volt a bázisütem előrelátó csökkentése a túra kezdetén, sokszor kellett a pumpáknak még ezt a kisebb beadási sebességet is teljesen leállítaniuk. A túrázók alaposan kihasználták ezeket a lehetőséget, mert bár volt szükség leállításra a túra előtti és az azt követő napon is, a hegymászás közben ez szignifikánsan gyakrabban fordult elő mind az LGS (első-második nap: $0,07 \pm 0,26$ vs. $1,07 \pm 1,44$ alkalom/nap, $p<0,0001$ és második-harmadik nap: $1,07 \pm 1,44$ vs. $0,20 \pm 0,41$ alkalom/nap, $\mathrm{p}=0,001$ ), mind a PLGM (első-második nap: $0,87 \pm 1,13$ vs. $1,07 \pm 1,44$ alkalom/nap, $\mathrm{p}=0,015$ és $1,07 \pm 1,44$ vs. $0,20 \pm 0,41$ alkalom/nap, $\mathrm{p}=0,035)$ tekintetében. Ugyanezt találjuk, ha azt vizsgáljuk, hogy mennyi idő telt el az egyes napokon úgy, hogy a pumpa „állt”, vagyis a bázisütem 0 volt. Ez az idő a túra napján jelentős mértékben megnőtt $(91,89 \pm 55,05$ vs. $359,00 \pm 105,30$ perc, $\mathrm{p}<0,0001$ ), míg a harmadik napra egyértelműen visszacsökkent $(359,00 \pm 105,30$ vs. $192,67 \pm 136,52$ perc, $\mathrm{p}=0,001)$. Hasonló eltéréseket találtunk, ha a túra előtti és az azt követő napokat hason-

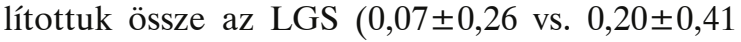
alkalom/nap, $\mathrm{p}=0,007)$ és a teljes felfüggesztés idejének $(91,89 \pm 55,05$ vs. $192,67 \pm 136,52$ perc, $\mathrm{p}=0,047)$ tekintetében.

A szenzor által mért cukorszintek átlaga érdemben nem változott a túra napján az azt megelőző naphoz képest $(8,10 \pm 1,38$ vs. $7,98 \pm 1,22 \mathrm{mmol} / \mathrm{l}$, $\mathrm{p}=0,962)$. Ez összességében nem jelenti feltétlenül azt, hogy kevesebb hypoglykaemia fordult elö az extrém testmozgás során, hiszen nagy vércukoringadozás esetén is kialakulhat a viszonylag jó átlag. Ezért célszerủ az átlagos (vér)cukor mellett azt is vizsgálni, hogy mennyi időt töltöttek a diabetesesek összességében az előre definiáltan kórosan alacsony, illetve kórosan magas vércukortartományon belül. Erről az úgynevezett görbe alatti terület (AUC) értéke nyújt információt. Itt sem látunk lényegi különbséget a két nap között akár az alacsony $(0,03 \pm 0,07$ vs. $0,06 \pm 0,07, p=N S)$, akár a magas $(1,23 \pm 1,04$ vs. $1,51 \pm 0,85, \mathrm{p}=\mathrm{NS})$ tartományokat nézzük. Vagyis elmondhatjuk, hogy összességében nem változtak a (vér)cukrok az extrém testmozgás ellenére sem. A (vér)cukrok átlaga mérsékelten emelkedett a túra utánra $(7,98 \pm 1,22$ vs. $8,59 \pm 0,67 \mathrm{mmol} / \mathrm{l}, \mathrm{p}=0,045)$, de ez semmiképpen sem magyarázható esetleges Somogyi-effektussal, hiszen a magas értékek aránya lényegében nem változott (magas [vér]cukorhoz tartozó AUC: $1,51 \pm 0,85$ vs. $1,54 \pm 0,53, p=0,781)$. Az átlag emelkedésében inkább az játszhatott szerepet, hogy érthető módon - a harmadik napra lecsökkent az alacsony tartományon belül eltöltött idő aránya $(0,06 \pm 0,07$ vs. $0,02 \pm 0,03, p=0,015)$. 


\section{Megbeszélés}

Az irodalmi adatokkal ${ }^{14,15,16}$ egyezően saját tapasztalatunk szerint is megbízhatóan működik a szenzoros inzulinpumpa-rendszer és képes a jelentős vércukoresések elhárítására még extrém fizikai aktivitás során is. Ráadásul a PLGM úgy csökkenti az alacsony vércukorszint kialakulásának esélyét, hogy elmaradnak a Somogyi-effektusnak megfelelő utólagos vércukor-emelkedések. ${ }^{15}$

Megfigyelésünk arra is rávilágít, hogy az 1-es típusú diabetesszel élők számára sem lehetetlen komoly sportteljesítményt elérni a hypoglykaemiától való félelem nélkül. Természetesen egy extrém mértékủ terhelés komoly felkészülést és biztonsági előkészületeket igényel, de szenzoros inzulinpumpa használatával elérhető 1-es típusú diabetesszel élők számára is, mint ahogy erről lengyel szerzők is beszámoltak hegyi ultramaratonfutók kapcsán. ${ }^{16}$

Közlésre érkezett: 2018. október 24.

Közlésre elfogadva: 2019. január 16.

A szerzö levelezési címe:

\section{Dr. Török András}

Borsod-A.-Z. Megyei Központi Kórház és Egyetemi

Oktatókórház, Gyermekdiabetológia

3526 Miskolc, Szentpéteri kapu 72-76.

E-mail: drtorokandras@gmail.com
Irodalom

1. Egészségügyi szakmai irányelv - A diabetes mellitus kórismézéséról, a cukorbetegek antihyperglykaemiás kezelésérôl és gondozásáról felnőttkorban (szerk.: Jermendy Gy, irta: Gaál Zs, Gerő L, Hidvégi T, Jermendy Gy, Kempler P, Winkler G, Wittmann I). Diabetologia Hungarica 2017; 25(1): 3-77. doi: $10.24121 /$ dh. 2017.1

2. Bohn B, Herbst A, Pfeifer M, Krakow D, Zimny S, Kopp F, et al. for the DPV Initiative: Impact of physical activity on glycemic control and prevalence of cardiovascular risk factors in adults with type 1 diabetes: a cross-sectional multicenter study of 18,028 patients. Diabetes Care 2015; 38(8):1536-1543. doi:10.2337/dc15-0030

3. Lukács A, Mayer K, Török A, Kiss-Tóth E, Barkai L: Better cardiorespiratory fitness associated with favourable metabolic control and health-related quality of life in youths with type 1 diabetes mellitus. Acta Physiol Hung 2013; 100(1): 77-83. doi:10.1556/APhysiol.100.2013.1.7

4. Apor P, Rádi A: Fizikai aktivitás a cukorbetegség kialakulásának és progressziojának fékezésére - a cukorbetegek edzése. Diabetologia Hungarica 2009; 17(2): 143-149.

5. Pivovarov JA, Taplin CE, Riddell MC: Current perspectives on physical activity and exercise for youth with diabetes. Pediatr Diabetes 2015; 16(4): 242-255. doi:10.1111/pedi.12272

6. Barkai L, Lukács A: Testmozgás és 1-es típusú diabetes gyermek- és serdülókorban: szisztematikus irodalmi áttekintés. Diabetologia Hungarica 2017; 25(3): 204-216.

7. Brazeau AS, Rabasa-Lhoret R, Strychar I, Mircescu H: Barriers to physical activity among patients with type 1 diabetes. Diabetes Care 2008; 31(11): 2108-2109. doi:10.2337/dc08-0720

8. Gaál Zs: A glukózmonitorozás lehetóségei és kérdései. Diabetologia Hungarica 2017; 17(1): 5-13.

9. Slattery $D$, Choudhary $P$ : Clinical use of continuous glucose monitoring in adults with type 1 diabetes. Diabetes Technol Ther 2017; 19(52): S55-S61. doi:10.1089/dia.2017.0051

10. Karges B, Schwandt A, Heidtmann B, Kordonouri O, Binder E, Schierloh U, et al: Association of insulin pump therapy vs. insulin injection therapy with severe hypoglycemia, ketoacidosis, and glycemic control among children, adolescents, and young adults with type 1 diabetes. JAMA 2017; 318(14): 1358-1366. doi:10.1001/jama.2017.13994

11. Biester T, Kordonouri 0 , Holder M, Remus K, Kieninger-Baum D, Wadien T, et al: "Let the algorithm do the work": reduction of hypoglycemia using sensor-augmented pump therapy with predictive insulin suspension (SmartGuard) in pediatric type 1 diabetes patients. Diabetes Technol Ther 2017; 19(3): 173-182. doi:10.1089/dia.2016.0349

12. Steineck I, Ranjan, A, Nørgaard K, Schmidt S: Sensor-augmented insulin pumps and hypoglycemia prevention in type 1 diabetes. I Diabetes Sci Technol 2017; 11(1): 50-58. doi:10.1177/1932296816672689

13. Riddell M, Perkins BA: Exercise and glucose metabolism in persons with diabetes mellitus: perspectives on the role for continuous glucose monitoring.J Diabetes Sci Technol 2009; 3(4): 914-923. doi:10.1177/193229680900300439

14. Abraham MB, Davey R, $O^{\prime} G$ rady MJ, Ly $\Pi$, et al.: Effectiveness of a predictive algorithm in the prevention of exercise-induced hypoglycemia in type 1 diabetes. Diabetes Technol Ther 2016; 18(9): 543-550. doi:10.1089/dia.2016.0141

15. Garg S, Brazg RL, Bailey TS, Buckingham BA, Slover RH, Klonoff DC, et al.: Reduction in duration of hypoglycemia by automatic suspension of insulin delivery: the in-clinic ASPIRE study. Diabetes Technol Ther 2012; 14(3): 205-209. doi:10.1089/dia.2011.0292

16. Gawrecki A, Zozulinska-Ziolkiewicz D, Matejko B, Hohendorff J, Malecki MT, Klupa T: Safe completion of a trail running ultramarathon by four men with type 1 diabetes. Diabetes Technol Ther 2018; 20(2): 147-152. doi:10.1089/dia.2017.0296 